\title{
OPTIMASI DESAIN GATING SYSTEM PROSES DIE CASTING COLD CHAMBER MENURUNKAN CACAT PRODUK
}

\author{
1Dedy Krisbianto, ${ }^{2}$ Dwi Rahmalina, ${ }^{2}$ Agri Suwandi \\ Program Studi Magister Teknik Mesin, Universitas Pancasila, Jakarta \\ Email: krisbianto.dedy@yahoo.co.id
}

\begin{abstract}
Abstrak
Untuk mendapatkan hasil akhir produk yang baik pada proses produksi die casting cold chamber dengan bahan material aluminium ADC12 yang sering dihadapi untuk proses akhir proses produksi die casting antara lain porosity, sebelum pembuatan produk perlu dilakukan simulasi desain produk. Modifikasi desain produk dapat memakai program Solidworks baik untuk desain simulasi 3D, manfaat simulasi desain produk untuk mengetahui secara dini hasil produk yang akan dibuat, yang perlu diperhatikan adalah desain gate runner pada die casting karena dapat mengetahui kecepatan aliran logam ke desain produk, untuk mengatuhui aliran cairan logam yang masuk ke dies, bisa melakukan simulasi dengan memakai program simulasi MAGMASOFT dapat mendeteksi cacat produk akhir tanpa melakukan try and error manual.Diperlukan parameter yang dilakukan, slow shot, A 0.4, B $0.5 \mathrm{~m} / \mathrm{s}$, fast shot, A3.5, B $3.5 \mathrm{~m} / \mathrm{s}$, temperatur Molten, 670, B $670{ }^{\circ} \mathrm{C}$, cycle time, A $55, B 55$ detik, diameter biskuit, A85, B $90 \mathrm{~mm}$. Dalam desain modifikasi gating system A dari hasil X-Ray porosity pada produk mencapai $12.18 \%$ sedangkan pada desain modifikasi B menunjukan penurunan cacat porosity mencapai 3.17\% sehingga desain B dapat direkomendasikan untuk produk masal.
\end{abstract}

Kata kunci: Tempat Roda Gigi Transmisi, program desain Solidworks, Program Simulasi Magma, gate runner

\section{Abstract}

To get a good product end result in the cold chamber die casting production process with ADC12 aluminum material that is often faced for the final process of the die casting production process, among others, porosity, before the product manufacture needs a product design simulation. Product design modification can use the Solidworks program both for $3 D$ simulation design, the benefits of product design simulation to find out early the product results to be made, which needs to be considered is the gate runner design on die casting because it can determine the speed of metal flow to product design, to comply with flow metal liquid that goes into dies, can do simulations using the simulation program MAGMASOFT can detect defects in the final product without manual try and error. Parameters needed are done, slow shot, A 0.4, B $0.5 \mathrm{~m} / \mathrm{s}$, fast shot, A3.5, B $3.5 \mathrm{~m} / \mathrm{s}$, Molten temperature, 670, B $670{ }^{\circ} \mathrm{c}$, cycle time, A 55, B 55 seconds, biscuit diameter, A85, B $90 \mathrm{~mm}$. In the design of the gating system A modification of the X-Ray porosity results on the product reached $12.18 \%$ while in the modified design $B$ showed a decrease in porosity defects reaching $3.17 \%$ so that design $B$ could be recommended for mass products.

Keywords: Transmission Gear Spot, Solidworks design program, Magma Simulation Program, gate runner

\section{PENDAHULUAN}

Die casting adalah salah satu metode pembentukan untuk memproduksi sejumlah besar produk dengan lead time pendek dan permukaan yang baik dengan tekanan injeksi yang tinggi dari paduan cor, desain produk, desain aliran dan gate, dan lain-lainnya. Namun dalam kenyataannya, desain itu di casting telah dilakukan dengan metode trial and error, yang menyebabkan kerugian ekonomi dan waktu [5]

Solusi untuk menghilangkan cacat permukaan kasar atau porosity ada beberapa tindakan yang dilaksanakan: Menaikkan temperatur die, cairan logam. Percepat kecepatan gate, untuk memperpendek waktu pengisian. Memasang over flow atau gas vent [4]

Kemajuan terpenting dalam peradaban adalah mengenal produksi masal . cetakan HPDC adalah salah satu teknologi untuk produksi massal. Karena kecepatan tinggi dari logam cair, aluminium die-casting sangat kompleks dimana momentum aliran merupakan hal penting 
dalam proses pengisian cetakan. Sebenarnya dibagian yang kompleks, hampir tidak mungkin untuk menghitung kinerja pengisian cetakan yang tepat dengan menggunakan pengetahuan eksperimental. Karena kondisi ini dalam prosedur desain, simulasi menjadi lebih penting. Simulasi dapat membuat sistem casting optimal dan juga meningkatkan kualitas casting dengan sedikit percobaan. Keuntungan terbesar menggunakan program simulasi adalah penghematan waktu dan biaya dari desain tata letak pengecoran. Pemilihan kondisi HPDC terutama bergantung pada pengalaman dan keahlian dari seorang pekerja individu di industri pengecoran. Akumulasi pengetahuan yang sistematis dari proses die casting merupakan hal yang penting untuk mendapatkan kondisi proses yang optimal. Dalam industri pengecoran saat ini, paradigma pengembangan produk bergeser dari trial-and-error tradisional ke proofof-concept berdasarkan simulasi Computer Aided Engineering (CAE)-enabled. Karena kecepatan tinggi perilaku dinamis dari sistem pengecoran dalam kondisi kerja, aluminium die casting adalah proses yang sangat kompleks di mana momentum aliran merupakan masalah penting dalam proses pengisian cetakan. Dalam paradigma pengembangan produksi baru, simulasi CAE memainkan peran penting karena memodelkan seluruh proses casting dan mengungkapkan perilaku dinamis dari system casting [6].

Proses High Presure die casting (HPDC) telah banyak digunakan untuk memproduksi berbagai macam produk dengan akurasi dimensi tinggi dan produktivitas. Tingkat produksi ini sudah lebih cepat dibandingkan dengan metode lain dan itu adalah sebuah metode yang ekonomis dan effisien untuk memproduksi komponen dengan kekerasan permukaan rendah dan akurasi dimensi tinggi, semua komponen otomotif utama aluminium dapat di proses dengan teknologi ini. Gejala yang terjadi hasil proses akhir produk antara lain adalah porosity permukaan kasar, porosity kecil yang mungkin muncul akibat sebagian kecil cairan logam metal tidak menyatu [10].

Dalam melihat hasil dari disain sebelum dibuat produk maka dilakukan simulasi desain untuk Magmasoft Simulation. Adalah pemadatan 3D dan paket aliran fluida yang digunakan dalam industri die casting untuk memodelkan aliran logam cair dan solidifikasi dalam dies. MAGMASOFT menggunakan metode beda hingga untuk menyelesaikan perpindahan panas dan massa pada grid persegi panjang. Ini bisa menjadi alat yang berguna untuk mensimulasikan beberapa aliran logam cair tetapi juga memiliki beberapa keterbatasan [18].

Penelitian ini dilakukan untuk menurunkan cacat produk akhir pada proses die casting cold chamber yang ada pada saat ini. Pada penelitian ini dilihat dari perubahan desain sistem saluran die casting dengan menggunakan simulasi program magmasoft. Pembuatan modifikasi desain ini sedang dalam proses. Pada penelitian yang dilakukan sebelumnya adalah sebagai berikut:

1. Prediksi simulasi aliran smoothed particle Hydrodynamic (SPH) 3D dan validitasi untuk tekanan tinggi die casting komponen otomotif, simulasi ini hampir sama dengan simulasi magmasoft [7]

2. Casting cacat analisis menggunakan desain percobaan Design Of Experiment (DoE) dan teknik simulasi pengecoran berbasis komputer [8]

3. Analisis dan optimalisasi sistem gating untuk braket ujung komutator karya ini menggunakan paket aliran 3D guna melihat aliran [19]

Berdasarkan hasil penelitian sebelumnya diatas, dapat diketahui bahwa terdapat keterbaruan dalam penelitian yang akan dilakukan, untuk optimasi desain gating system pada proses die casting cold chamber ini dengan menganalisis cacat produk menggunakan program simulasi magma soft V. 
Tujuan penelitian ini adalah untuk menganalisis akar permasalahan dari cacat produk penutup roda gigi transmisi motor matik yang sering terjadi pada produk bermaterial Aluminium pada proses Aluminium Die Casting, agar didapatkan setting parameter proses yang tepat sehingga dapat memperbaiki permasalahan cacat produk di perusahaan tersebut : Mendapatkan desain modifikasi dan simulasi gating system die casting pada proses High Presure Die Casting (HPDC) Cold Chamber.

Mendapatkan analisis gating system pada proses die casting. Mendapatkan analisis pengaruh perubahan desain gating system terhadap proses die casting. Mendapatkan analisis perbandingan antara modifikasi tambahan pada gating system A dan modifikasi gating system B pada proses Pengecoran High Presure Die Casting (HPDC) cold chamber

\section{METODE PENELITIAN}

Dalam penjelasan tentang prosedur penelitian dapat digambarkan dalam bentuk flow chart seperti terlampir di bawah ini, dalam flow chart ini menunjukan alur dari penelitian yang dilakukan
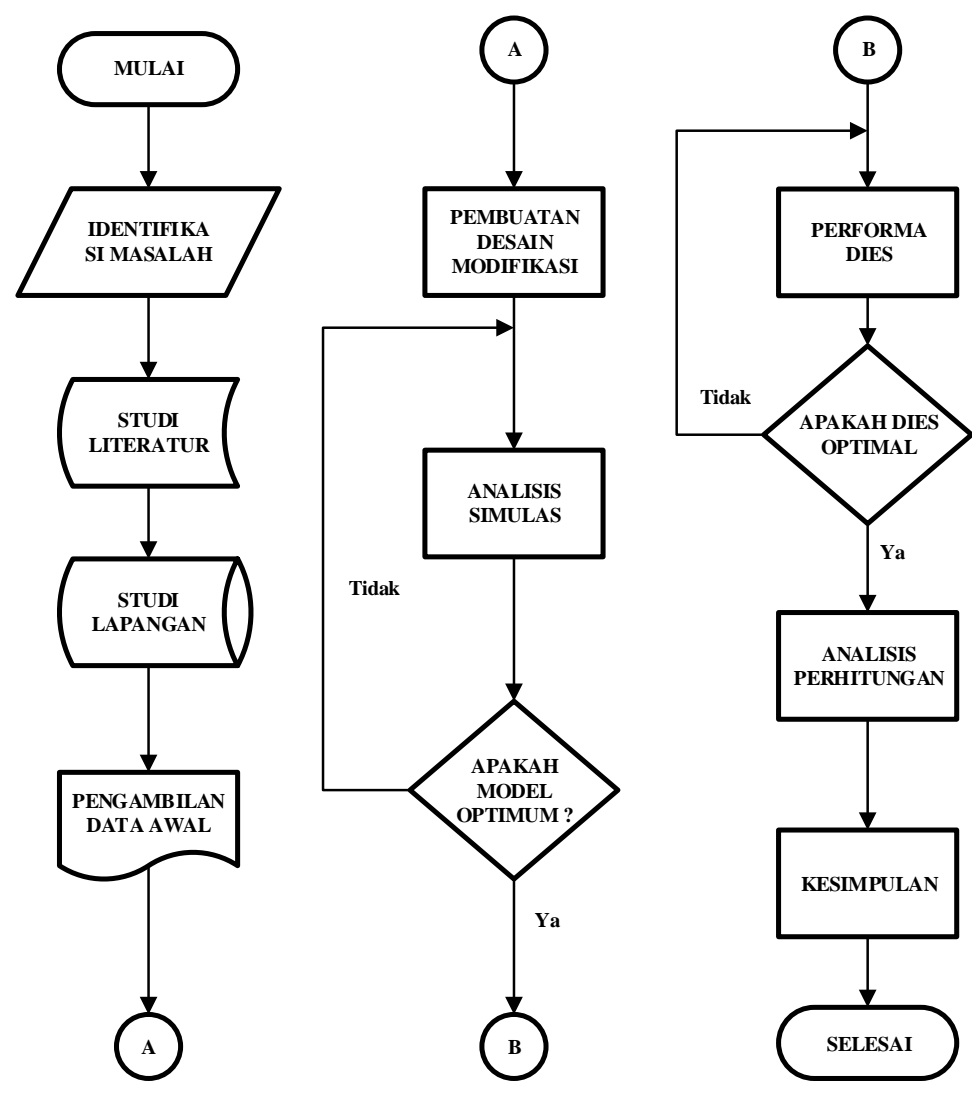

Gambar 1. Sistematika Alur Penelitian

\section{HASIL DAN PEMBAHASAN}

\subsection{Proses Desain Sistem Runner dan Gating Sistem}


Untuk menurunkan reject porosity produksi, pada produk tempat penutup roda gigi transmisi motor matik diperlukan desain modifikasi pada gating system adapun perubahan modifikasi

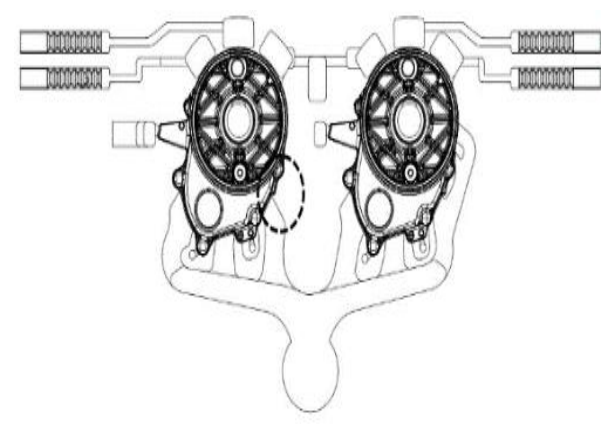

gating system dengar (a) uat modifikasi 2 desain terlihat pada g

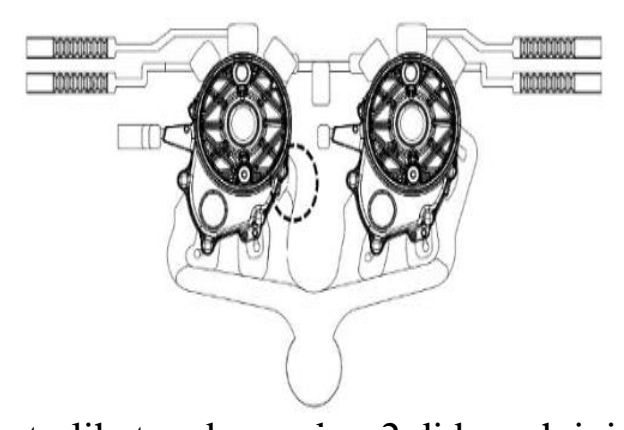

(b)

Gambar. 2. Desain Penambahan Runner Gate 2 Cavity, (a) desain awal sebelum ada penambahan (b) desain sesudah ada penambahan gate

Pada gambar 2 menunjukkan ada penambahan saluran gating pada desain (b) terlihat di tanda lingkaran terputus antara desain (a) dan (b), fungsi dari penambahan untuk merubah aliran kecepatan cairan logam ke produk menjadi lebih cepat sampai ke produk dan lebih pendek aliran.

\subsection{Kalkulasi Desain}

(a)

(b)

Untuk modifikasi desain gating system yang tepat untuk mengurangi porosity pada proses desain roda gigi transmisi motor matik, terbagi beberapa tahapan yang harus dilalui langkah awal yang di lakukan menghitung kalkulasi desain die

\subsection{Perhitungan Tonnage}

Area yang diproyeksikan termasuk overflow dan sistem umpan

Ac $x$ Factor $\left(\mathrm{mm}^{2}\right)$

Dimana diketahui sesuai desain

$=15800 \times 1,4=22120 \mathrm{~mm}^{2}$

Tekanan Injeksi x FOS (Factor of safety)

Ps x P1 xFOS (T)

Dimana :

Ps = Area yang di proyeksikan termasuk overflow dan sistem umpan $\mathrm{mm}^{2}$

$\mathrm{Pi}=$ Tekanan Injeksi [bar]

FOS $=$ Factor of safety $($ standar keamanan pabrik) $=1.05$

Jadi $=22120 \times 600 \times 10^{-2} \times 1.05=139.356 \mathrm{~T}$

Maka dapat memilih mesin $350 \mathrm{~T}$ sesuai dengan tonase yang diperoleh dari perhitungan

\subsection{Shot Weigh}

$V_{c}+V_{0 f}$ (Tidak termasuk biskuit) $\quad=\mathrm{mm}^{3}$

(3)

$435106 \times 1.4=609148.4 \mathrm{~mm}^{3}$ 
Tersedian ukuran plunger di mesin $350 \mathrm{~T}$ diameter ujung $60-70 \mathrm{~mm}$. Yang kita bisa pilih 60 mm diameter ujung

\subsection{Mengisi perhitungan rasio}

Rasio penuh adalah rasio volume logam untuk menembak volume lengan, nilai untuk rasio isi ini dapat dterima untuk proses tersebut, karena itu adalah vakum die casting dibantu, nilainya dihitung sebagai 0,083

Mengisi rasio $=40 \%$

Mengisi perhitungan waktu $=\mathrm{k}\left[\mathrm{Ti}-\mathrm{Tf}+\mathrm{s}^{*} \mathrm{z}\right] \mathrm{T} /[\mathrm{Tf}-\mathrm{Td}] \operatorname{detik}$

(4)

$$
\begin{gathered}
\mathrm{t}=[0.0346[640+570+2.5 \times 3.8] \times 2.5\} /\{570-80] \\
=14.27 / 390=0,0365 \mathrm{~s}
\end{gathered}
$$

\subsection{Perhitungan Gating}

Perhitungan tingkat pengisian menggunakan rumus

Tingkat pengisian = volume aliran logam melalui gate / rongga mengisi Waktu = $435106 \mathrm{~mm}^{3} / \mathrm{sec}$

\subsection{Menghitung area gate}

Area gate $=$ Tingkat Pengisian $/$ kecepatan gate $=\mathrm{mm}$

(5)

$$
\begin{aligned}
& =435106 / 40500 \\
& =10.74 \mathrm{~mm}^{2}
\end{aligned}
$$

( kecepatan gate harus $40.50 \mathrm{~m} / \mathrm{s}$ )

\subsection{Hitung panjang gate}

Panjang gate $=$ area gate $/$ ketebalan gate $=\mathrm{mm}$

(6)

$$
\begin{aligned}
& =10.74 / 1.6 \\
& =6.7 \mathrm{~mm}
\end{aligned}
$$

\subsection{Menghitung luas runner}

Area runner $=2 \mathrm{x}$ area gate $=\mathrm{mm}^{2}$

(7)

$$
=2 \times 10.74=21.48 \mathrm{~mm}^{2}
$$

\subsection{Menghitung lebar runner}

$$
\begin{aligned}
\text { Lebar runner } & =\sqrt{(2 \mathrm{x} \text { area } \text { runner }}=\mathrm{mm} \\
& =\sqrt{(2 \times 21.48} \\
& =6.55 \mathrm{~mm}
\end{aligned}
$$




\subsection{Menghitung kedalaman runner}

Kedalaman runner $=$ kedalaman runner $/ 2=\mathrm{mm}$

(9)

$$
=6.55 / 2=3.27 \mathrm{~mm}
$$

Tetapi dalam panjang gate komponen yang tersedia adalah $55 \mathrm{~mm}$ Oleh karena itu area gate yang disimpan adalah $=1.6 \times 55=88 \mathrm{~mm}^{2}$ Aturan yang baik adalah bahwa jika area gate sama dengan 1/4 dari massa komponen maka kita akan mendapatkan casting diisi yang baik Massa komponen diketahui $=330 \mathrm{gm}$ Oleh karena itu diperlukan area gate minimum $=330 / 4$ $=82,5 \mathrm{~mm}^{2}$ Maka dari itu gate thickness $\mathrm{ke} 1.6 \mathrm{~mm}$, panjang gate $55 \mathrm{~mm}$ dan gate kecepatan $40 \mathrm{~m} / \mathrm{sec}$ akan menghasilkan automasi

\section{PERFORMA DIES}

\subsection{Hasil simulasi program magma $V$}

Untuk memenuhi produktivitas pada proses die casting perlu dilakukan simulasi terlebih dahulu guna untuk mengurangi cacat produksi akhir saat dilakukan pengerjaan masal. Adapun yang dilakukan simulasi menggunakan program magmasoft V. Tujuannya untuk mengetahui lebih awal terjadinya cacat pada desain, sebelum dijadikan dies pada gambar 3 menunjukkan

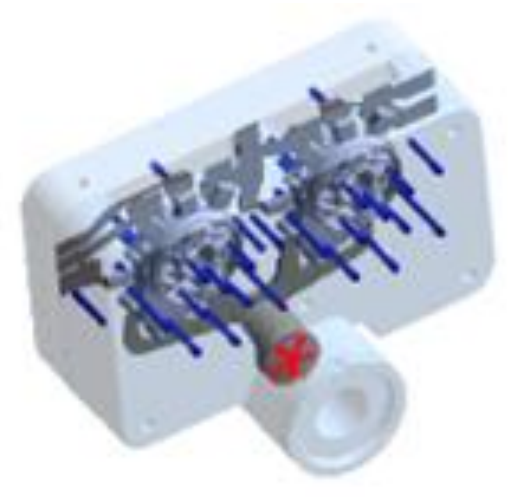

(a)

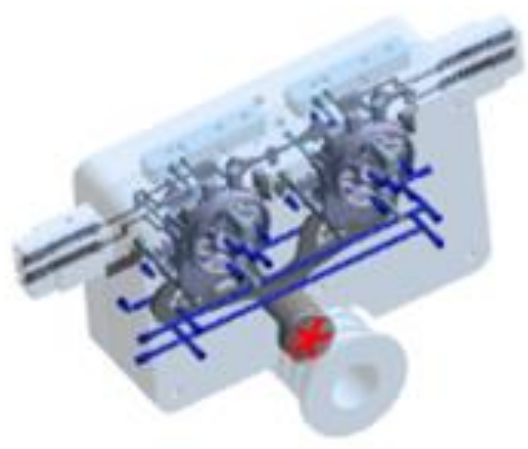

(b)

Gambar. 3. Desain geometry (a) desain geometry pada posisi awal, (b) desain geometry perubahan pada gate dan pembesaran pada biskuit gambar geometri sebelum di lakukan simulasi pada software magma $\mathrm{V}$

\subsection{Parameter Die Casting}

Langkah awal sebelum melakukan simulasi perlu dilakukan persiapan untuk Parameter pengisian cairan logam die casting pada saat masuk ke proses pencetakan die. Adapun persiapan parameter dapat dilihat dari tabel 1. 
Tabel. 1 Parameter Desain A dan Desain B

\begin{tabular}{lccc}
\hline \multicolumn{1}{c}{ Parameter } & DESAIN & DESAIN & Satuan \\
& A & B & \\
\hline Slow shot & 0.4 & 0.5 & $\mathrm{~m} / \mathrm{s}$ \\
Fast shot & 3.5 & 3.5 & $\mathrm{~m} / \mathrm{s}$ \\
Temperatur Molten & 670 & 670 & ${ }^{\circ} \mathrm{C}$ \\
Cycle Time & 55 & 55 & Detik \\
Diameter Biskuit & 85 & 90 & $\mathrm{~mm}$ \\
\hline
\end{tabular}

Setelah parameter di persiapkan selanjutnya di lakukan simulasi produk, hasil simulasi produk terlihat di gambar 4. dari gambar terlihat kecepatan aliran ke dies.

\subsection{Proses Hasil Pengisian pada Simulasi Magma Soft}

Proses simulasi pengisian aliran terlihat pada gambar 4 menunjukkan waktu dan volume aliran di simulasi produk, serta terlihat bahwa kecepatan aliran pada modifikasi A lebih panjang waktunya dari padmodifikasi B lebih pendek waktunya, hal ini disebabkan karena ada perubahan penambahan gate di bagian produk, kondisi ini sesuai dengan literatur yang menyatakan bahwa semakin pendek waktu tempuh aliran die casting maka semakin baik untuk pemadatan cairan logam ke produk sehingga dapat menghasilkan produk akhir yang baik dan mengurangi cacat produk.

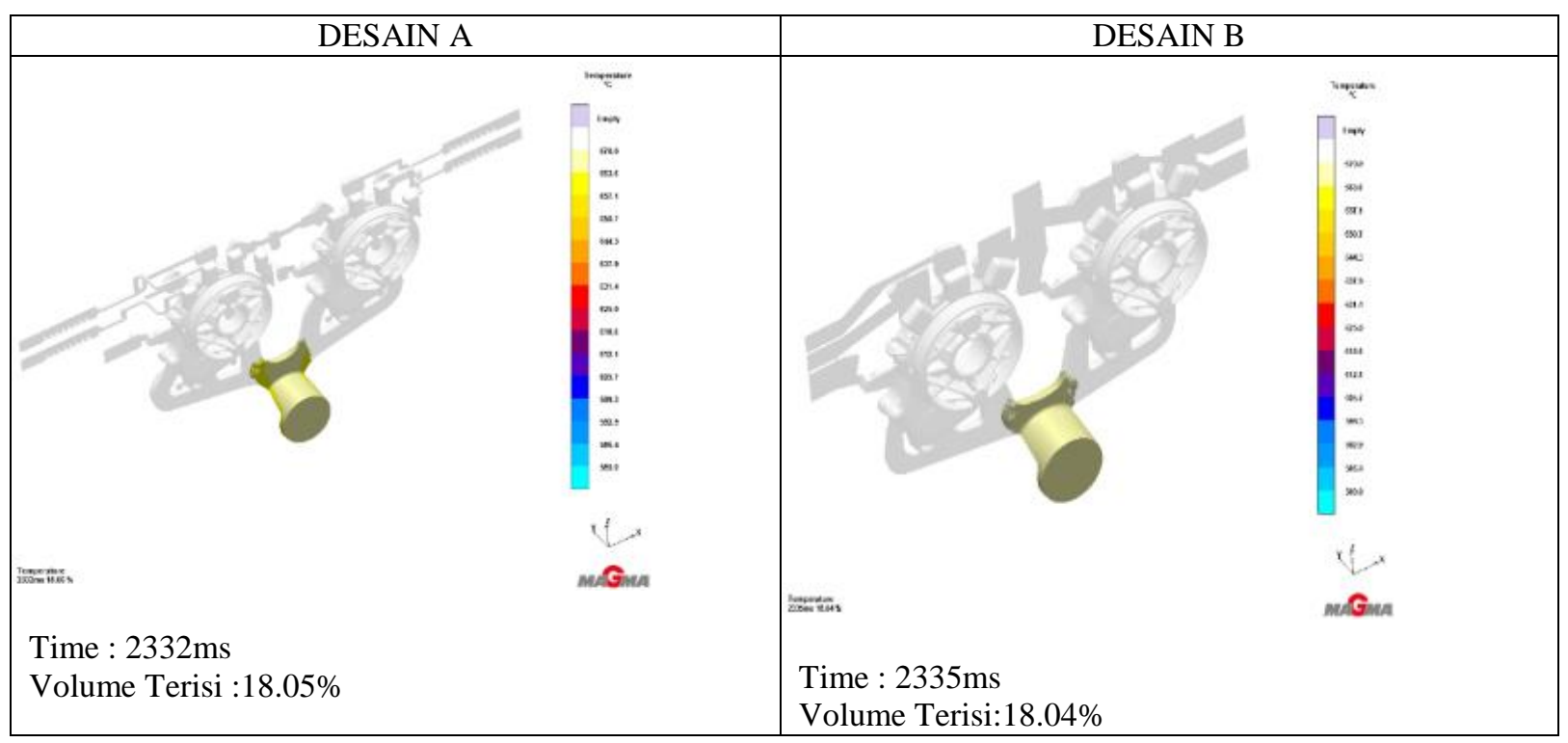




\begin{tabular}{|c|c|c|c|}
\hline Time :2342ms & 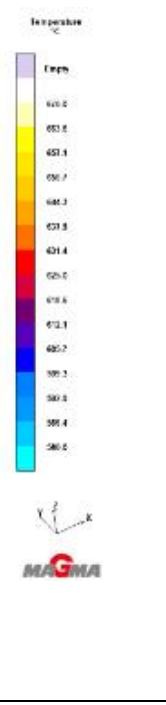 & $\begin{array}{l}\text { Time : } 2344 \mathrm{~ms} \\
\text { Volume Terisi : } 28.05 \%\end{array}$ & 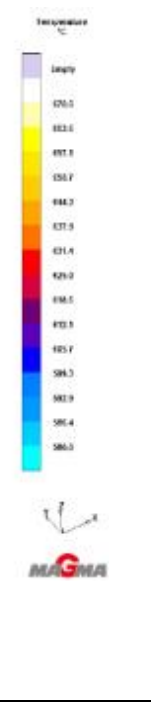 \\
\hline $\begin{array}{l}\text { Time : } 2359 \mathrm{~ms} \\
\text { Volume Terisi } 48.01 \%\end{array}$ & 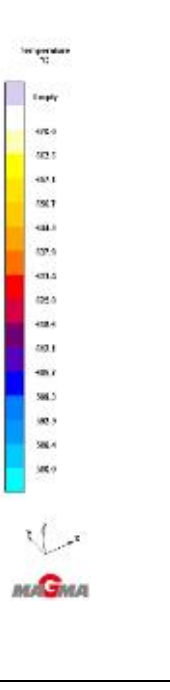 & $\begin{array}{l}\text { Time : } 2361 \mathrm{~ms} \\
\text { Volume Terisi : } 48.01 \%\end{array}$ & 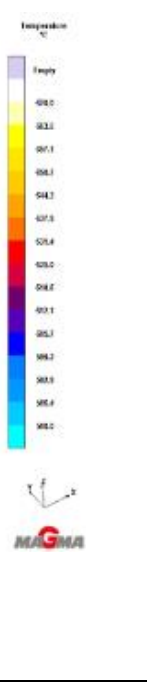 \\
\hline $\begin{array}{l}\text { Time :2385ms } \\
\text { Volume Terisi : } 78.00 \% \\
\end{array}$ & 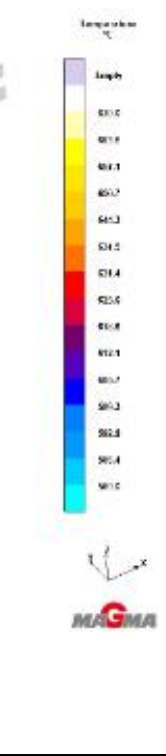 & $\begin{array}{l}\text { Time }: 2386 \mathrm{~ms} \\
\text { Volume Terisi : } 78.03 \%\end{array}$ & 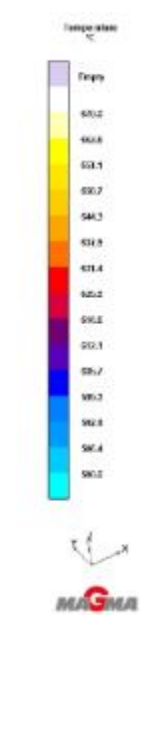 \\
\hline
\end{tabular}




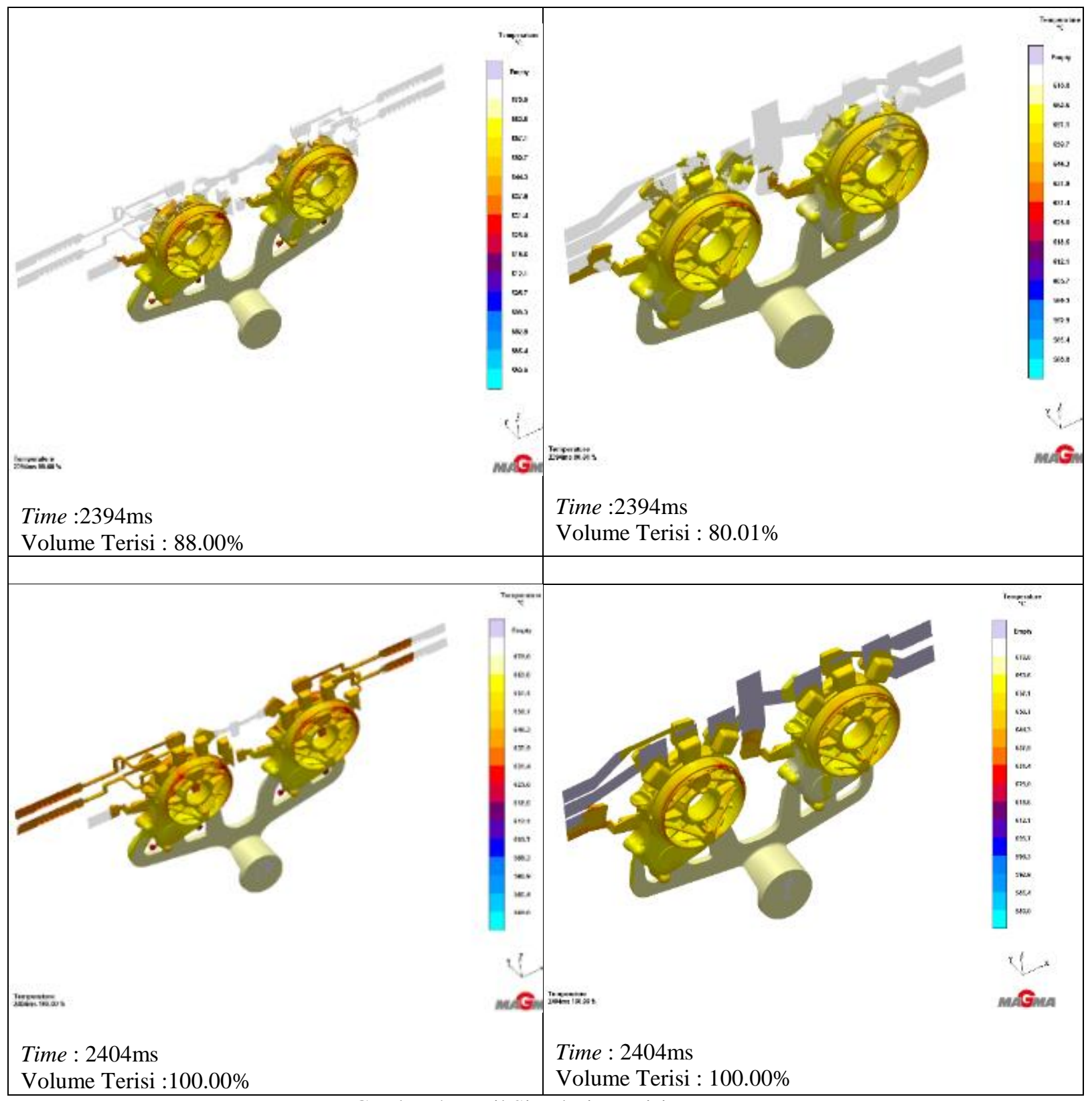

Gambar 4. Hasil Simulasi Pengisian Dies

Pada Tabel 2 memperlihatkan hasil dari nilai kecepatan aliran logam ke die casting dan prosentase pada aliran, dimana pada desaian B lebih cepat Volume terisinya dan waktu dibandingkan dengan modifikasi desain A untuk menuju 100\% pengisian

Tabel 2. Simulasi Pengisian Dies

\begin{tabular}{ccccc}
\hline \multirow{2}{*}{ No } & \multicolumn{2}{c}{ Pengisian A } & \multicolumn{2}{c}{ Pengisian B } \\
\cline { 2 - 5 } & Volume Terisi (\%) & Time $(\mathrm{mS})$ & Volume Terisi (\%) & Time (ms) \\
\hline 1 & $18.06 \%$ & 2.332 & $18.04 \%$ & 2.335 \\
2 & $28.01 \%$ & 2.342 & $28.05 \%$ & 2.344 \\
3 & $48.01 \%$ & 2.359 & $48.01 \%$ & 2.361 \\
4 & $78.00 \%$ & 2.385 & $78.03 \%$ & 2.386 \\
5 & $88.00 \%$ & 2.394 & $88.01 \%$ & 2.394 \\
6 & $100.00 \%$ & 2.404 & $100.00 \%$ & 2.404 \\
\hline
\end{tabular}




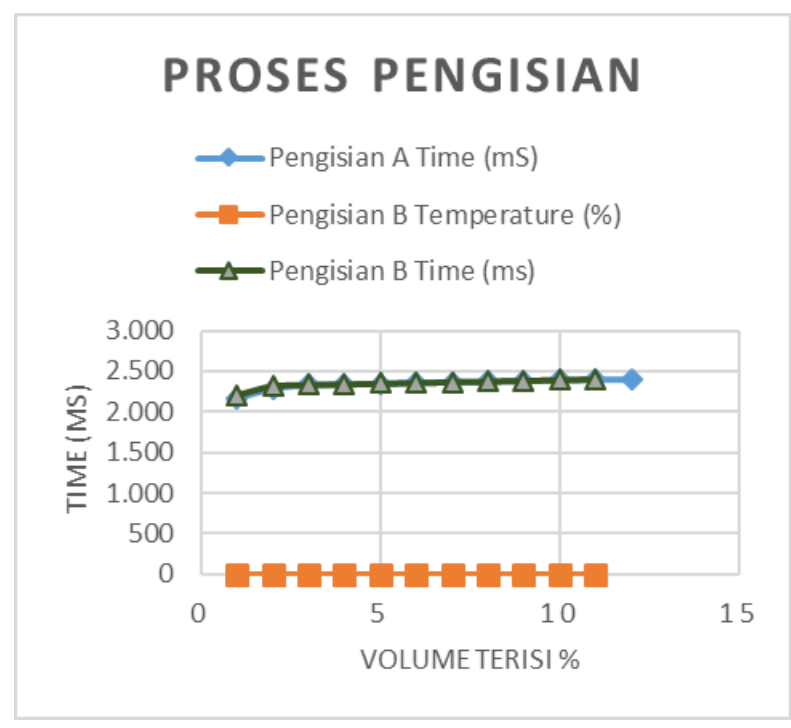

Gambar 5. Grafik hasil simulasi pengisian pada dies

Dapat dilihat pula dari gambar 5 menunjukkan gambar grafik aliran desain modifikasi A dan desain modifikasi B menunjukkan hasil dari desain modifikasi B lebih pendek aliran logamnya sehingga lebih cepat untuk akhir produksi.

\subsection{Proses Pemadatan Logam}

Proses simulasi pemadatan logam terlihat pada gambar 6 menunjukkan waktu dan volume pemadatan logam di simulasi produk, serta terlihat bahwa pemadatan pada modifikasi A lebih singkat waktunya 18.002 s sehingga tidak mencapai $100 \%$ hanya mencapai $98.52 \%$ hal ini mengakibatkan pemadatan yang tidak sempurna sehingga banyak cairan yang masih terjebak di produk ini akan mengakibatkan cacat produk. Sedangkan pada modifikasi B waktu pemadatan 56589s dengan mencapai $100 \%$ untuk pemadatannya, maka hasil modifikasi B sangat baik pemadatannya tidak terjebak di area produk terjebaknya di area tambahan

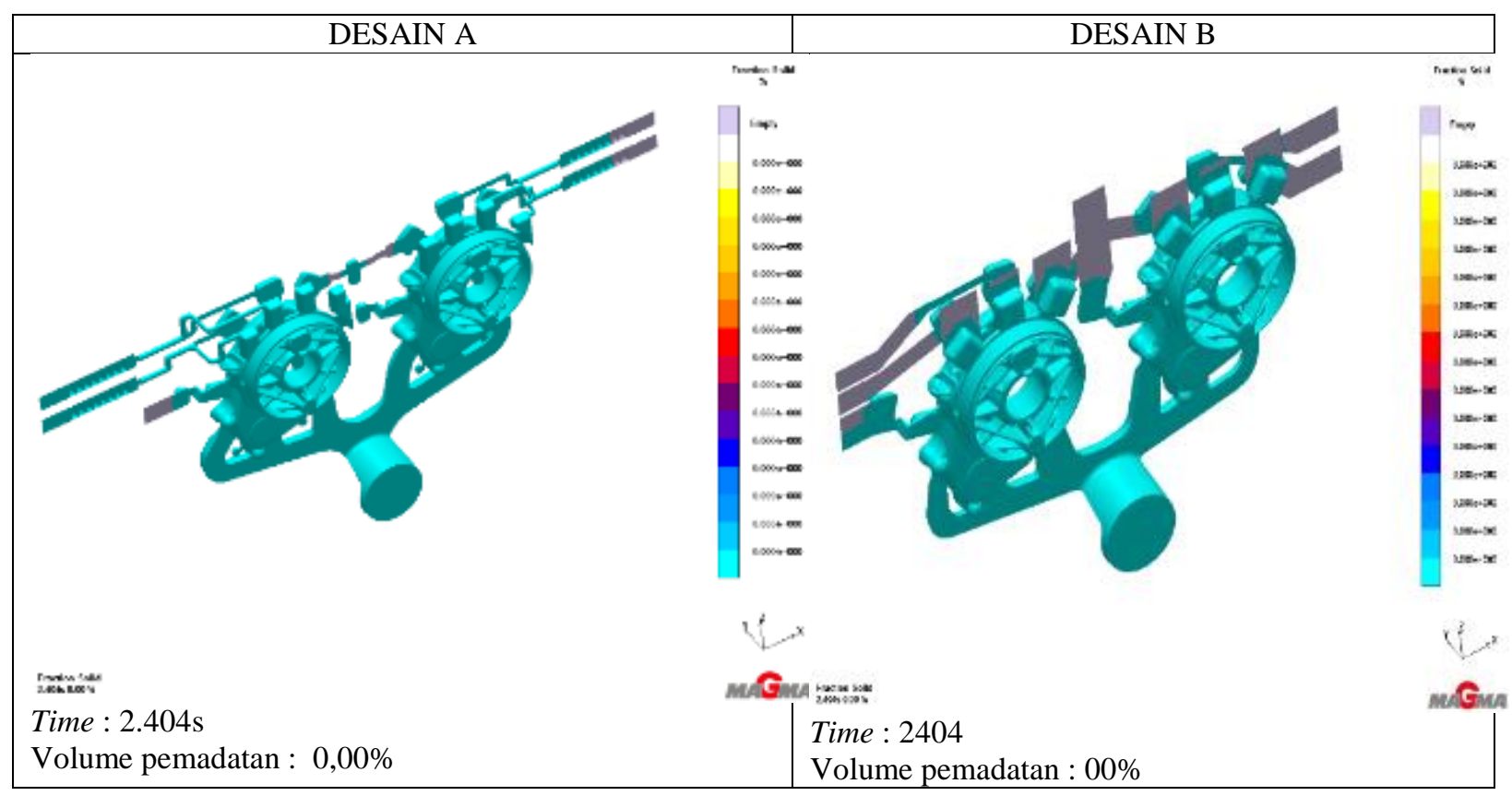




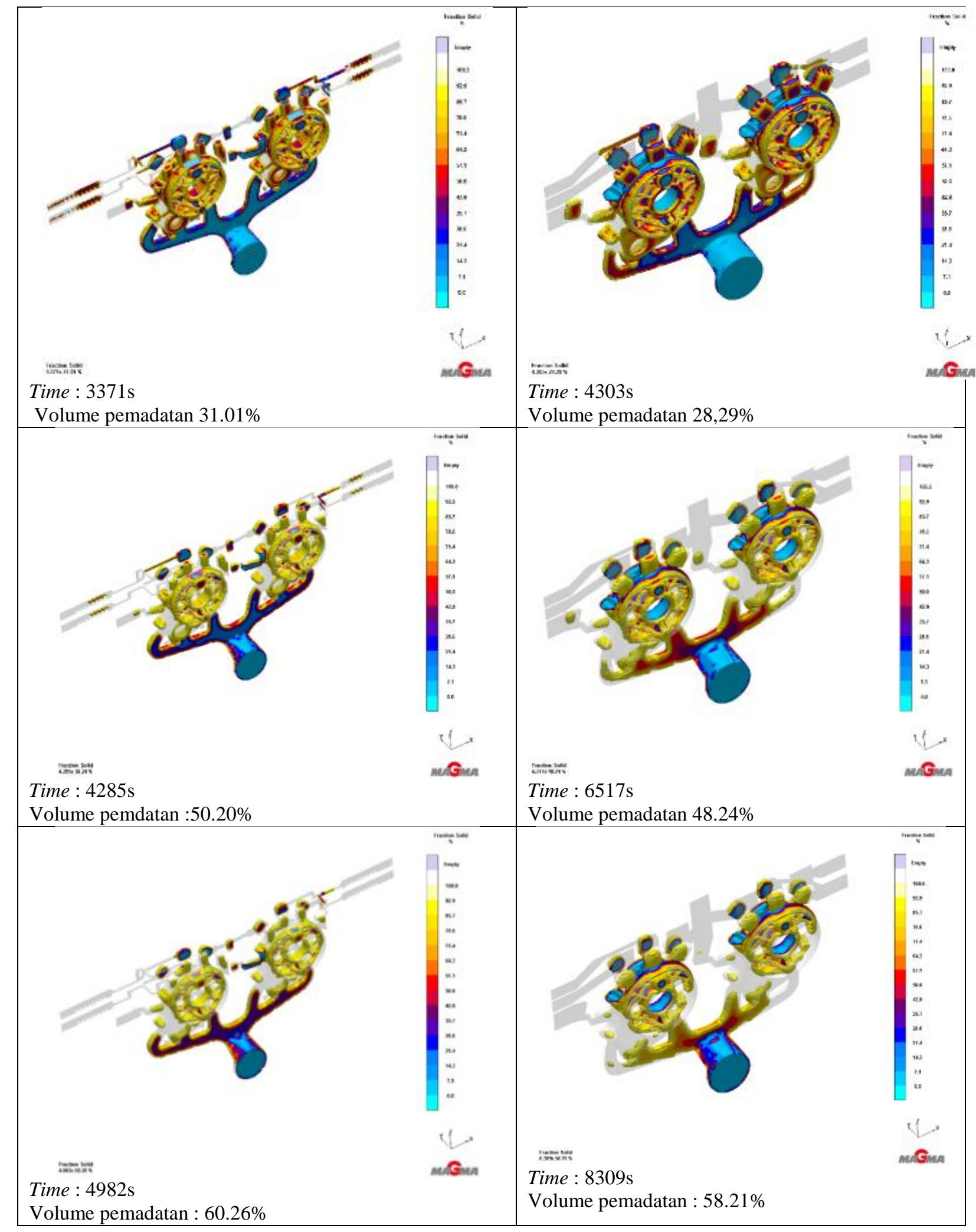




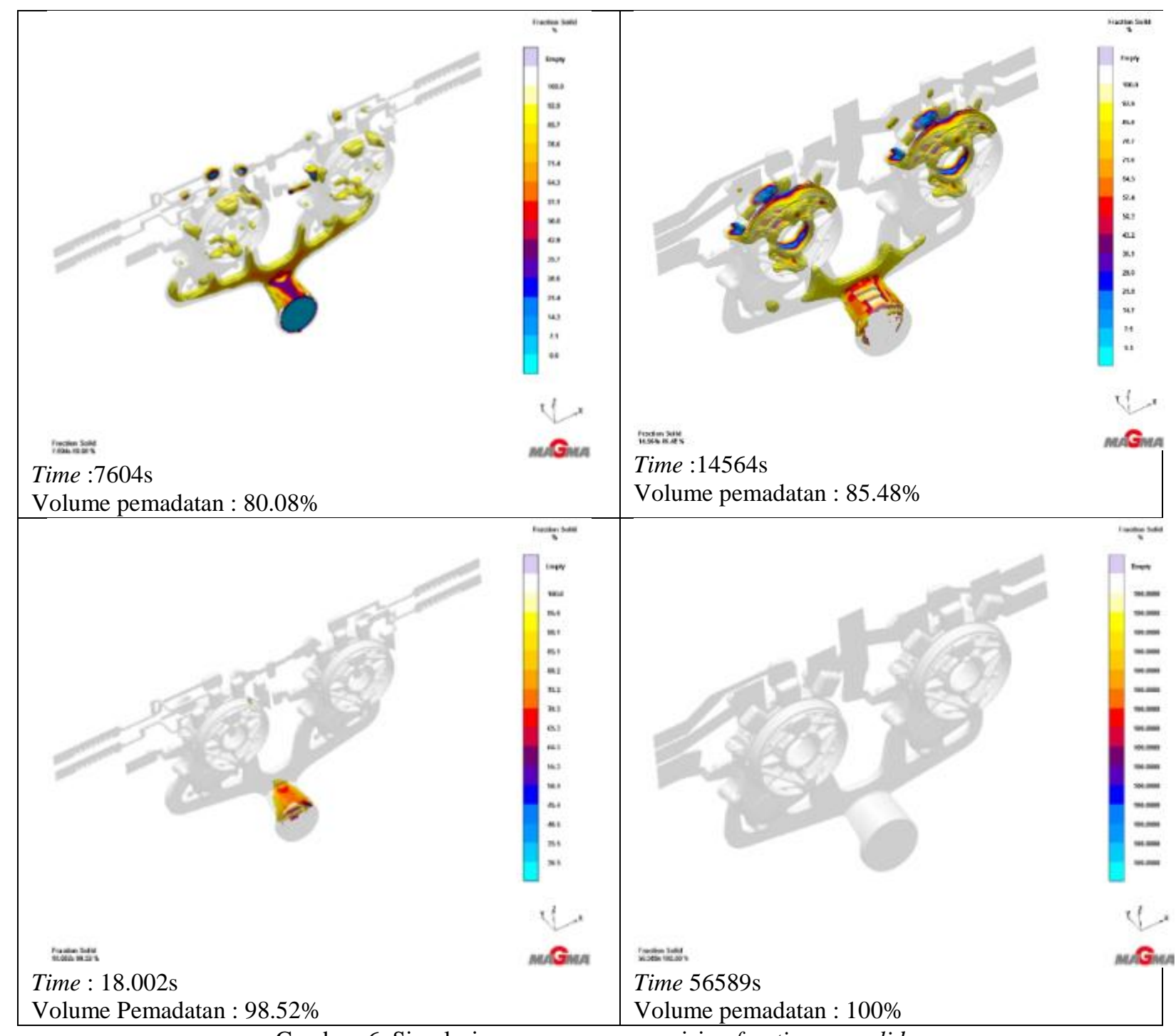

Gambar. 6. Simulasi magma proses pengisian fraction solid

Pada Tabel 3 memperlihatkan hasil dari nilai Volume pemadatan aliran logam ke die casting dan prosentase pada proses pemadatan dapat di lihat akhir dari pemadatan untuk desain A proses pemadatannya lebih cepat tetapi tidak mencapai maksimal $100 \%$, sedangkan pada modifikasi B terlihat lebih lama akan tetapi pencapaian pemdatannya mencapai $100 \%$.

Tabel . 3 hasil simulasi proses pemadatan cairan logam

\begin{tabular}{ccccc}
\hline \multirow{2}{*}{ No } & \multicolumn{2}{c}{ Poses Solidifikasi A } & \multicolumn{2}{c}{ Proses Solidifikasi B } \\
\cline { 2 - 5 } & Volume pemadatan (\%) & Time $(\mathrm{s})$ & Volume pemadatan (\%) & Time (S) \\
\hline 1 & $0.00 \%$ & 2.404 & $0.00 \%$ & 2404 \\
2 & $31.01 \%$ & 3.371 & $28.29 \%$ & 4303 \\
3 & $50.20 \%$ & 4.285 & $48.24 \%$ & 6517 \\
4 & $60.26 \%$ & 4.982 & $58.21 \%$ & 8309 \\
5 & $80.08 \%$ & 7.604 & $85.48 \%$ & 14564 \\
6 & $98.52 \%$ & 18.002 & $100.00 \%$ & 56589 \\
\hline
\end{tabular}




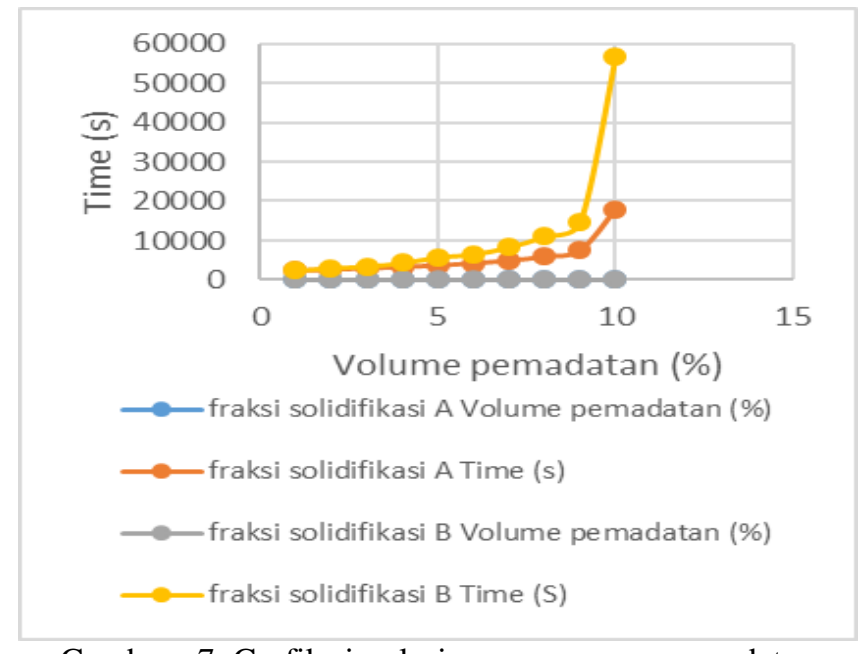

Gambar .7. Grafik simulasi magma proses pemadatan

Dari gambar 7 menunjukkan gambar grafik aliran desain modifikasi A dan desain modifikasi B hasil dari desain modifikasi B lebih lama pemadatan aliran logamnya sehingga mencapai $100 \%$ untuk akhir produksi.

\subsection{Hot Spot Fraction Solid (hasil titik panas pada proses pemadatan)}

Dari hasil gambar simulasi dari gating system pada gambar 8 , aliran molten pada akhir shot, saat beberapa area masih panas tetapi area lain sudah dingin. Hal ini bisa mempengaruhi kualitas pada produk yang sedang di produksi, telihat pada modifikasi A terlihat sebagian sudah dingin dan membeku diarea produk, sedangkan pada desain modifikasi B terlihat di area produk masih panas tidak cepat membeku. Sehingga pendinginnan dapat bersamaan pada area produk

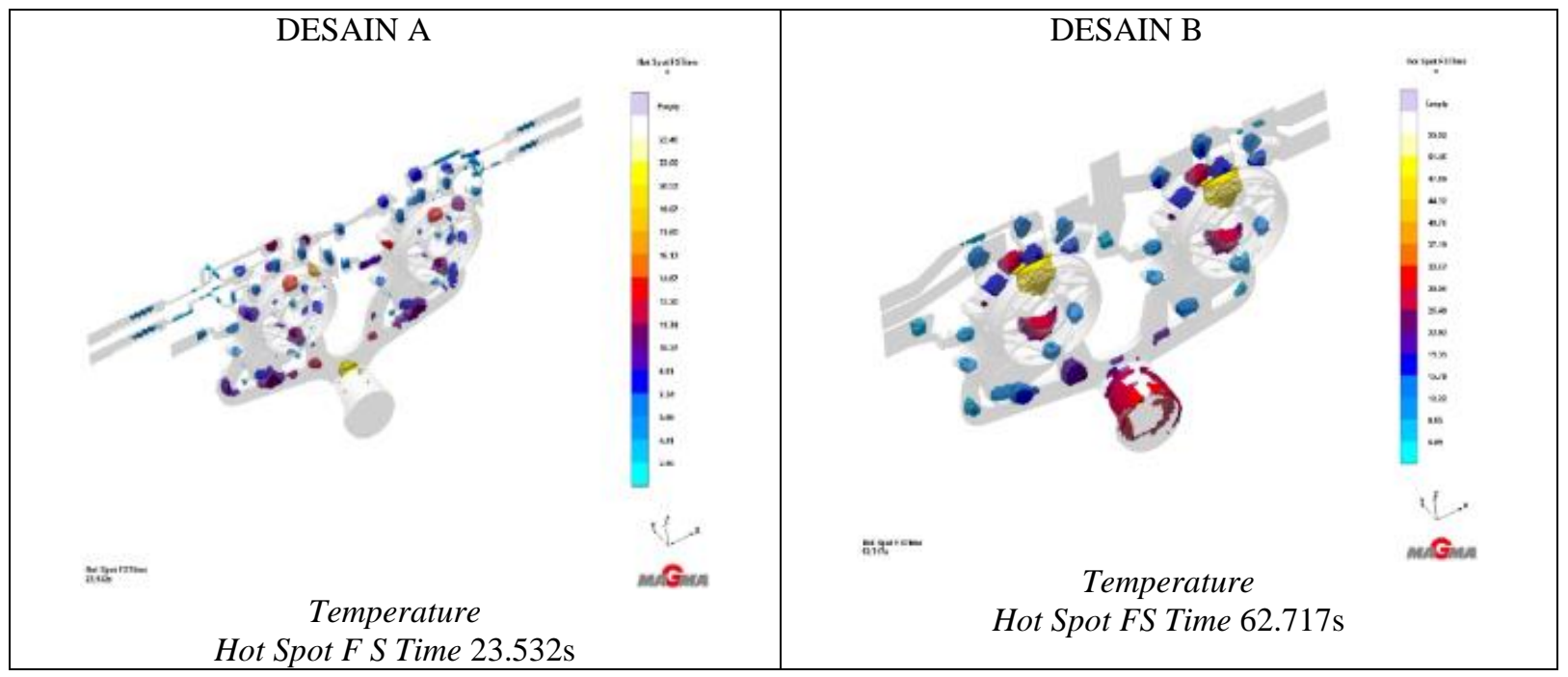

Gambar 8. hot spot fruction solid

\subsection{Result porosity (hasil Porositas)}

Dari hasil akhir simulasi pada modifikasi antara desain A dan B menunjukkan modifikasi A masih ada terdapat porosity sedangkan pada modifikasi B sudah tidak ada terlihat Porosity di bagian produk tetapi terjadi porosity di bagian penambahan aliran di biscuit dan chill vent dapat dilihat pada gambar 9. 


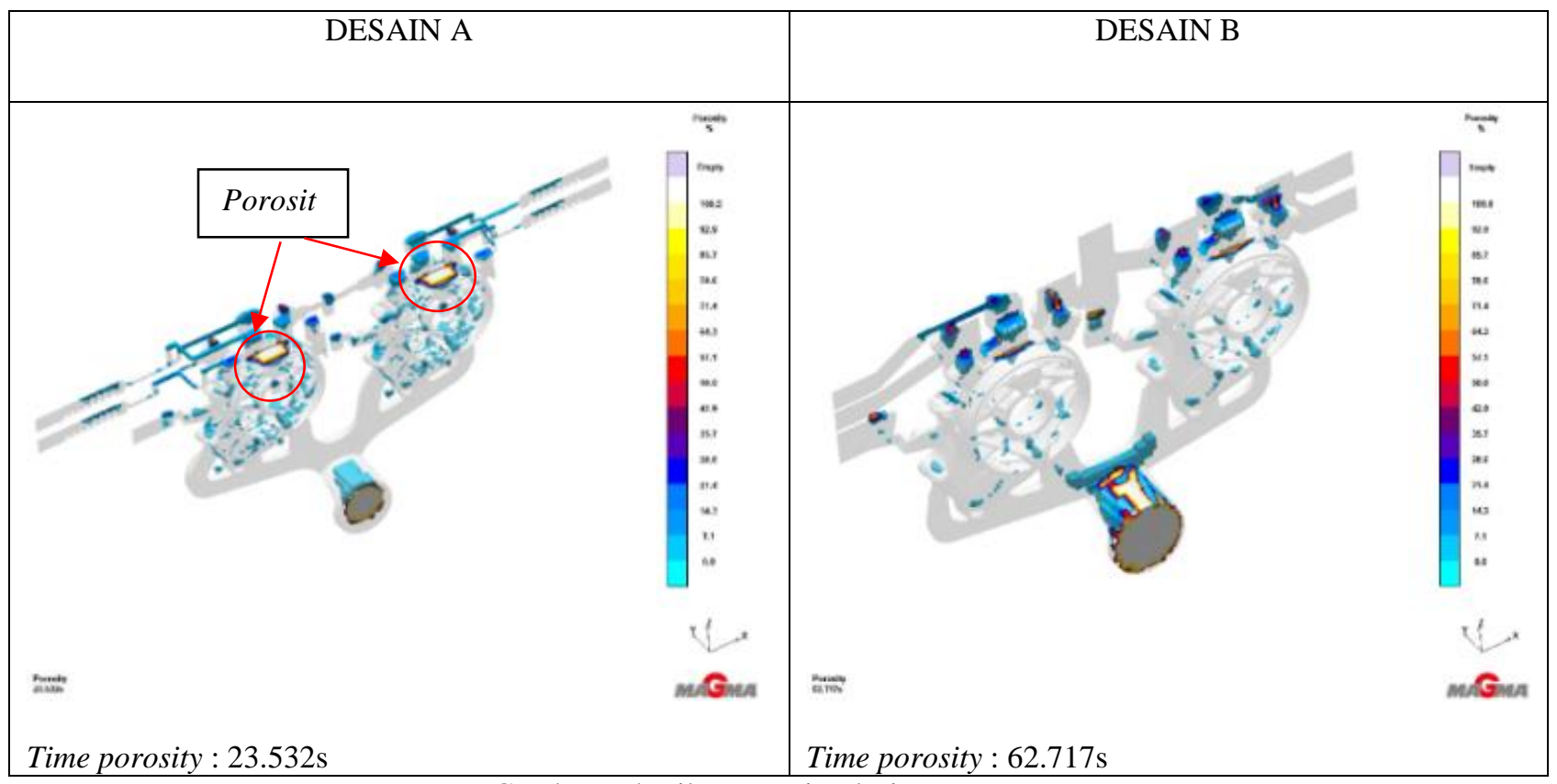

Gambar 9. hasil proses simulasi magma

\section{HASIL ANALISIS SIMULASI PRODUK}

Untuk mengetahui dari anasisis simulasi produk apakah produk itu baik atau tidaknya dapat melakukan penggunaan X-Ray sehingga dapat melihat berapa porsentase cacat produk dari akhir pengecoran. Dapat dilihat pada gambar 10

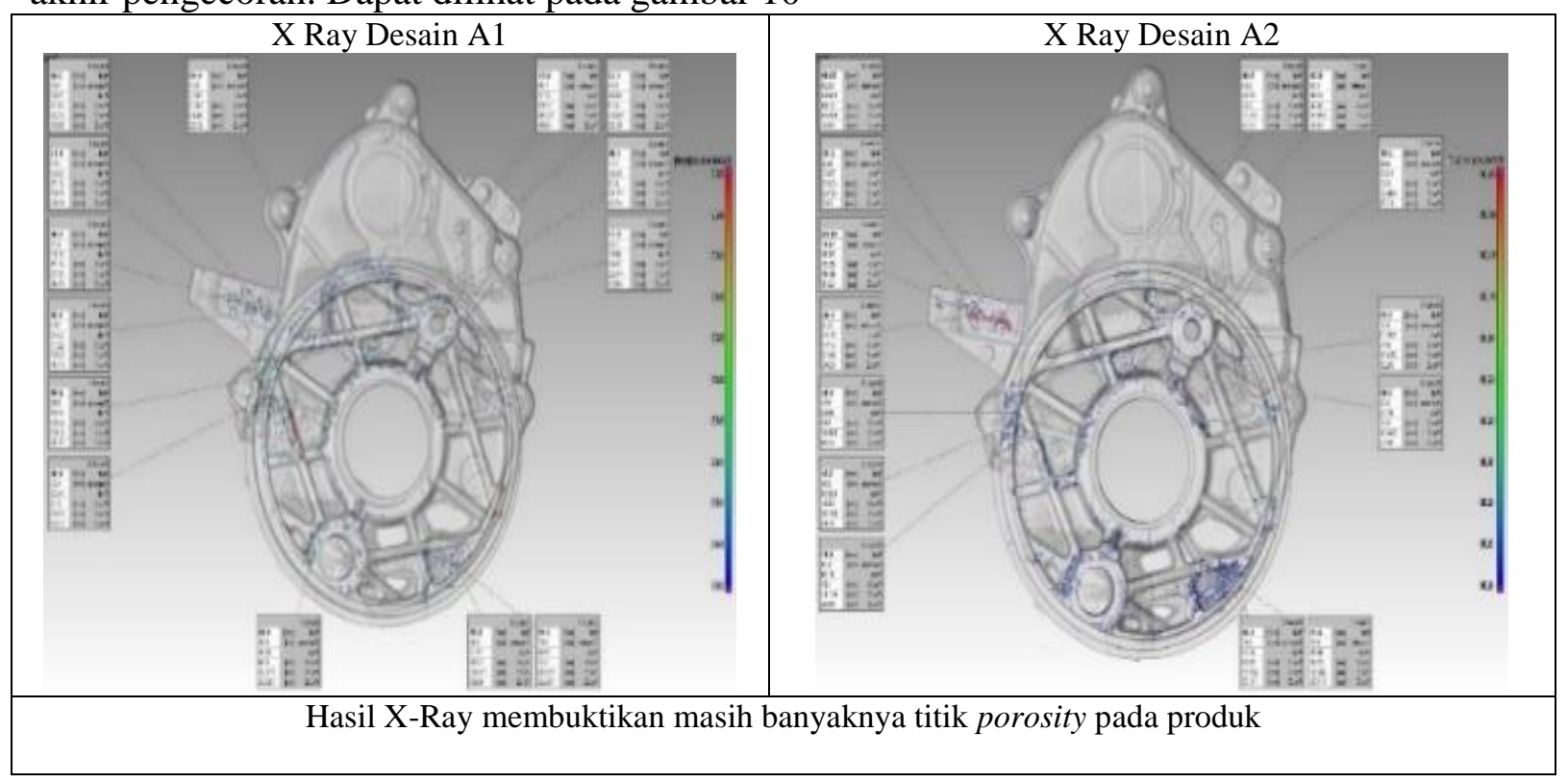




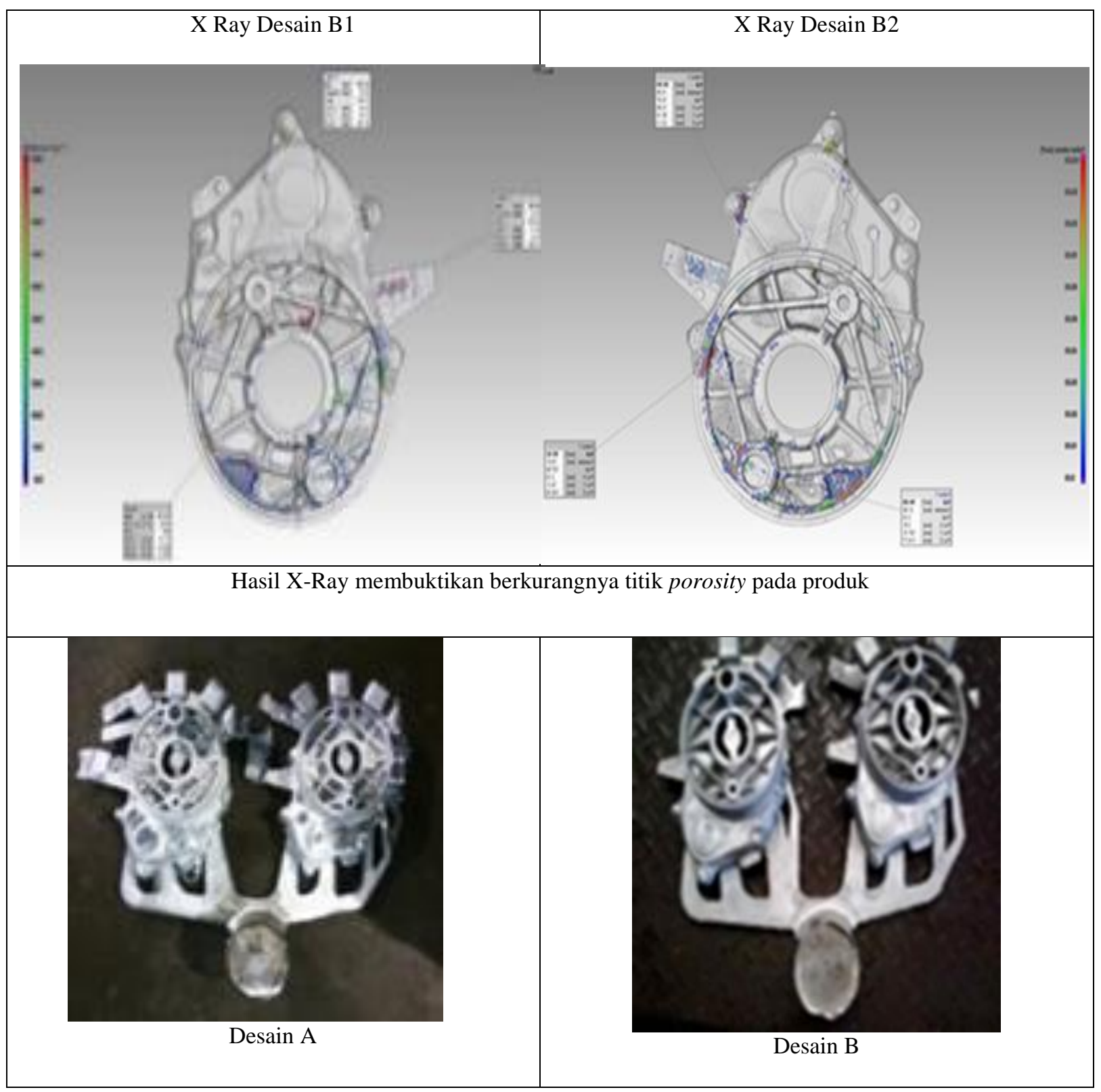

Gambar 10. hasil analisa dengan X-Ray

Berdasarkan hasil gambar X Ray pada produk A menampilkan banyaknya cacat porosity dibandingkan dengan produk $\mathrm{B}$ adapun jumlah perbadingan antara desain A dan desain B adalah sebagai berikut. Terlihat di tabel 4.4.

Dari hasil pengecekan X-Ray pada produk terlihat Prob atau Probability (kemungkinan Porosity) untuk desain A pada cavity A1 sebesar $819.8 \%$ dan untuk cavity A2 sebesar $1.105 .49 \%$, sedangkan pada desain B untuk cavity B1 sebesar $374.51 \%$ dan untuk cavity B2 sebesar $127.76 \%$. jadi dalam modifikasi antara desain A dan modifikasi desain B lebih baik desain B karena tingkat porositinya lebih rendah dibandingkan dengan desain modifikasi A. Untuk prosentase total keseluruhan produk A dan B dapat dilihat dari tabel 4.

\begin{tabular}{|c|c|c|c|c|c|}
\hline \multirow[t]{2}{*}{ Hasil } & \multicolumn{4}{|c|}{ Perbandingan Defect Produk (X-Ray) } & \multirow[t]{2}{*}{ Satuan } \\
\hline & Porosity A1 & Porosity A2 & Porosity B 1 & Porosity B2 & \\
\hline Prob & 819.8 & 1.105 .49 & 374.51 & 127.76 & $\%$ \\
\hline
\end{tabular}




$$
\begin{array}{cc}
\frac{\mathrm{PA} 1+\mathrm{PA} 2}{\mathrm{Ac}} \times 100 \% & \frac{\mathrm{PB} 1+\mathrm{PB} 2}{\mathrm{Ac}} \times 100 \% \\
\frac{819.8+1.105 .49}{15.800} \times 100 \% & \frac{374.51+127.76}{15.800} \times 100 \\
\text { Total defect Porosity A }=12.18 \% & \text { Total defect Porosity } \mathrm{B}=3.17 \%
\end{array}
$$

Tabel 4. Prosentase produk desain A dan desain B

Total prosentasi dari defect porosity pada desain A mencapai $12.18 \%$, sedangkan pada desain B lebih optimal penurunan porosity mencapai 3.17\%. jadi untuk pilihan yang baik untuk desain dapat direkomendasikan pada desain B dikarenakan lebih sedikit defect porosity

\section{KESIMPULAN}

Dari hasil analisis cacat produk dengan merubah atau modifikasi desain pada gating dies, material aluminium ADC12, terhadap produk penutup roda gigi transmisi (case mission) motor matik. Diberikan kesimpulan sebagai berikut :

1. Cacat produk dapat terjadi bila tidak tepat dalam menentukan setting parameter proses tekanan injeksi, temperatur injeksi serta waktu. Oleh sebab itu perlu dilakukan try and error sebelum dilakukan pembuatan dies, untuk pembuatan dies sendiri biayanya cukup mahal, agar tidak terjadi kesalahan dalam perhitungan produk diperlukannya simulasi desain dengan menggunakan program software Magma V

2. .Dari hasil analisis di lapangan yang terjadi cacat produk dikarenakan adanya aliran yang terjebak sehingga dapat menimbulkan hasil akhir yang tidak baik, dari analisis tersebut perlu dibuat perubahan desain yang terutama di bagian gating system untuk mempercepat atau memperpendek aliran agar aliran ke produk lebih padat dan merata saat proses solidifikasi.

3. Dalam hasil penelitian pengaruh perubahan pada optimasi desain gating system ternyata dari kedua desain antara desain A dan Desain B dengan perbedaan gating system ada perbedaan yang sangat signifikan dari kecepatan aliran dan saat pemadatan cairan logam, desain B hasilnya lebih baik dibandingkan dengan desain A.

4. Dalam desain modifikasi gating system A dari hasil X-Ray porosity pada produk mencapai total reject $12.18 \%$ sedangkan pada desain modifikasi B menunjukan penurunan cacat porosity mencapai $3.17 \%$, dilihat dari hasil simulasi pada grafik 4.5 dapat disimpulkan bahwa desain modifikasi B lebih baik hasil simulasinya dikarenakan waktu pemadatannya dapat mencapai $100 \%$, sedangkan untuk desain modifikasi A hanya mencapai $98.52 \%$, yang artinya masih ada cairan logam belum padat pada area produk, sehingga akan terjadi banyak cacat produk, oleh karena itu untuk produk masal desain B dapat direkomendasikan.

\section{REFERENSI}

M. Okayasua,*, Y, Ohkurab, S. Takasub, H. Ohfujic, T.Shiraishi . A study of the mechanical properties of $\mathrm{Al}-\mathrm{Si}-\mathrm{Cu}$ alloy (ADC12) produced by various casting processes, Materials Science and Engineering A543 (2012) pp 185-192

K.K. seo, H.K.Kwon, Simulation study and application on HPDC process with auto mobile part, Adv. Mater.Res 658 (2013) pp 281-286 
N.A.Dukare, R.M Metkar,N.A. Vidhate s.D.Hiwase Optimazation Of Gating System Using Flow Software : A Review, [journal] ISSN : 2277-7059 Volume 4 issue 1 (January 2014 ) pp 9

S.Janudoma, t. Rattanochaikul, R. Burapa, S. Wisutmethangoon, J. Wannasin. Feasibility of semi-solid die casting of ADC12 aluminium, Trans NonferrouS Met. Soc. China 20(2010) pp 1756.

J. C. Choi, T. H. Kwon, J. H, Park, Kim, C. H. Kim, A Study on Development of a Die Design System for Diecasting. Int J Adv Manuf Technol (2002) pp 1-8

Hyuk-Jae Kwon, Hong-Kyu Kwon. Computer aided engineering (CAE) simulation for the design optimization of gate system on high pressure die casting (HPDC) process, Robotics and Computer-Integrated Manufacturing 000 (2018) pp 1-7.

P.W. Cleary, J. Ha, M. Prakash, T. Nguyen. 3D SPH flow and validation for high pressure die casting of automotive components, Applied Mathematical Modelling 30 (2016) pp 1406-1427

Uday A dabade and rahul C. Bhedasgaonkar. Casting Defect Analisis using Design of Experiments (DoE) and Computer Aided Casting Simulation Technique. Procedia CIRP 7 (2013) pp 616-621

Franco Bonollo, Nicola Gramegna \& Giulio Timelli, High-Pressure Die-Casting: Contradictions and Challenges, volume 6724 April 2015 pp 901-908

Mohammad Sadeghi and Jafar Mahmoudi. Exsperimental and Theoretical Studies on the Effect of Die Temperature on the Quality of the Products in High-Presure Die-Casting Process.[journal] Hindawi Publishing Corporation Advances in Material Science and Engineering Volume 2012, Article ID 434605, pp 1

M.R.M. Kamal, N.A.M. Mustafa, E. Othman, N.F. Bazilah, M.S. Salleh. Analisis of High Pressure Die casting of Motorcycle Pressure Plate Using CAE Approach. International Design and Conference 7-8 September, 2017, Osaka Japan, pp 1-3

Doru Michael Stefanscu. Science and Engineering of Casting Solidification, Third Edition. Springer International Publishing Switzerland 2015. Pp 132

Setyo, Noor, Widodo, Sri, Pengaruh Bahan Pengikat Cetakan Pasir terhadap Sifat Fisis dan Mekanis Besi Tuang Kelabu, Jurnal Penelitian Inovasi Universitas Tidar Magelang, Desember 2013. Pp 2

Takasi Seno, Yutaka Ohtake, Yuji Kikuchi, Noriaka Saito, Hirosama Suzuki, Yuki Nagai. 3D Scanning based mold correction for planar and cylindrical part in aluminiumdie casting. [Journal] of Computational Design and Engineering 27 Januari (2015) pp 96-104.

Canyook, Rungsinee, et al, The effects of heat treatment on microstructure and mechanical properties of rheocasting ADC12 aluminium alloy, Material Today; Proceedings 5, 2018 pp 9476-9482 
Sulis Drihandono, Eko Budiyanto . Pengaruh Temperatur Tuang, Temperatur Cetakan, dan Tekanan Pada Pengecoran Bertekanan (High Pressure Die Casting/HPDC) Terhadap Kekerasan dan Struktur Mikro Aluminium Paduan Silikon (Al-Si 7,79\%). TURBO pISSN: 2301-6663, e-ISSN: 2447-250X Vol. 5 No. 1. 2016 pp 30

Jay M.Patel, Yagnang R. Pandya, Devang Sharma, Ravi C, Patel ; Varios Type Defects on Pressure Die Casting for Aluminium Alloys, ISSN (online): 2321-06130 1, 2017, PP 23-25

Josep HA, Paul W. Cleary, Mahes Prakash, Vladimir Alguine, Thang Nguyen and Craig Scott; SPH, Magmasoft And Water Analogue Modellings of Die Filling of a Servo Piston. Third International Conference on CFD in the Minerals and process industries CSIRO,10-12 DECEMBER 2003 PP 587-588

B.Vijaya Ramnath, C.Elanchezhian. Vishal Chandrasekhar, A.Arun Kumar. S. Mohamed Asif, G.Riyaz Mohamed, D. Vinodh Raj, C. Suresh Kumar ; Analysis and Optimization of Gating System for Commutattor end Bracket. (2014) pp 1312-1328

Mickell.P. Groover. 4th EDITION : PRINCIPLES of MODERN MANUFACTURING - SI VERSION.copyright (C) 2011 John Wiley \& Sons (Asia) Pte Ltd pp 205-208

Sulatin, Toto Rusianto, Sudarsono : Analisa Simulasi High Pressure Die Casting (HPDC) Aluminium Alloy Dengan Dua Varian Cooling Menggunakan Software Magma, 1 Desember 2014.- ISSN:2337-9928 pp 1-4

Claudio Favi, michele Germani, Marco Mandolini : Analytical cost estimation model in High Presure Die Casting. Procedia Manufacturing 11 (2017) pp 526-535

Sumber data PT. CHEMCO HARAPAN NUSANTARA

M.Hudori : Perbandingan Break Even Point (BEP) Antara Rencana dan Realisasi Project Customer's Price dengan Analisis Sensitivitas di Perusahaan Manufaktur,ISSN 2302934X, E-ISSN 2614-2910 Industrial Engineering Vol. 7 no.1 (2018), pp 36-42 